\title{
A Field Research on the Measurement of Psychological Capital in Organizations: Mersin Metropolitan Municipality Sample
}

\author{
Ahmet Turan Öztürk, Mesut Ersin \\ University of Turkish Aeronautical Association, Ankara, Turkey
}

\begin{abstract}
This study aimed to determine whether there were significant differences in terms of the variables, such as the gender, age, marital status, working time, education level, household income, and service period of 421 people working as civil servants and workers in Mersin Metropolitan Municipality for the sub-dimensions of psychological capital, which are hope, resilience, optimism, and self-efficacy, and significant correlations were also identified between the dimensions of psychological capital. The majority of municipal employees $(65.9 \%)$ had a high level of psychological capital perception while $34.1 \%$ had a low level of psychological capital perception.
\end{abstract}

Keywords: psychological capital, organizational behavior, statistical analysis

\section{Introduction}

In today's rapidly increasing competitive conditions, organizations need resources that will differentiate themselves from other organizations and provide sustainable competitive advantage. The most important and valuable resource of an organization is human capital, and the human resources can change the strategic perspective of the organization.

The concept of psychological capital refers to the positive psychological situation in which individuals have positive expectations that they will be successful today or in the future, have faith to overcome difficult tasks, and overcome problems to sustain success (Avey, Patera, \& West, 2006, p. 54). This definition distinguishes psychological capital from human capital (accumulation of knowledge, talent, and experience) and social capital (social relations and communication). Psychological capital, unlike traditional capital types, is expressed as the ability to successfully transfer human, social and economic capitals to the organization with the goal of employee productivity. Efforts to increase the levels of hope, resilience, self-efficacy, and optimism that make up the elements of psychological capital of the employees lead to creating a value and enhance their loyalty by developing trust in their organizations.

The primary purpose of the study was to determine whether there are significant differences in their psychological capitals in terms of demographic variables, such as gender, age, marital status, working time, educational status, household income and service period of civil servants and workers in Mersin Municipality

Ahmet Turan Öztürk, Dr., Faculty Member, Faculty of Business Administration, Department of Management, University of Turkish Aeronautical Association, Ankara, Turkey.

Mesut Ersin, graduate, scientist, Graduate School of Social Sciences, University of Turkish Aeronautical Association, Ankara, Turkey.

Correspondence concerning this article should be addressed to Ahmet Turan Öztürk, Faculty of Business Administration, Departmentof Management, University of Turkish Aeronautical Association, Etimesgut, Ankara 06790, Turkey. 
for hope, resilience, optimism, and self-efficacy, which are the sub-dimensions of psychological capital. In addition, the relationship between the dimensions of psychological capital and its effects constituted another sub-objective. The psychological capital perception of the employees was evaluated and the corporate profile was interpreted.

In the first part of the study, firstly the concept of organizational culture was explained and organizational behavior is discussed. Then, economic, human, social, and psychological types of capital were discussed.

In the second part of the study, the concept of psychological capital was explained in detail with reference to the other related concepts, its importance, and benefits. In addition, general information about psychology and positive psychology was given in this section.

In the third part, which is the application part of the study, the findings were evaluated by analyzing the survey conducted with the participation of civil servants and workers working in Mersin Municipality in order to measure psychological capital in organizations.

\section{Theoretical Framework}

\section{Capital and Types of Capital}

The concept of capital, in its most known meaning, is used as the tangible assets and money owned by an individual or organization. However, when this concept is discussed in depth, it can be determined that it is not only composed of material inputs. In this context, modern approaches examining capital only in terms of economic criteria led them to be criticized by new post-modern approaches. In this way, in general terms, capital has lost its aspect of being just an economic term, and other riches owned, such as being intellectual, knowledge, skills, social life, culture, and psychology have come to be considered as capital. In the following sections, apart from economic capital, some of the other types of capital brought by postmodern approaches are briefly mentioned (Hodgson, 2014, p. 1068).

\section{Economic Capital}

Economically, capital is considered equivalent to money. In this context, capital is seen as the investment of the institution in human resources, a company, or an enterprise. At the same time, all the assets of the institution with monetary value which they need in order to offer their products and services to the market are included in the capital (Hodgson, 2014, p. 1069).

\section{Human Capital}

The concept of human capital, which can be defined as labor quality, emerged with the beginning of $1960 \mathrm{~s}$ as an important component of the economy. Theodore W. Schultz's argument that the main source of economic growth is human and therefore cannot be ignored was effective in the recognition of the concept in history (as cited in Koç, 2013, p. 248).

Human capital can be described as the knowledge, skills, abilities, and competencies that an individual has as a result of the education and experience gained. Becker (1964), on the other hand, defined human capital as a high level of personal structure that includes knowledge, skills, and other characteristic features that one uses to create added value (as cited in Banerjee, 2013, p. 223).

\section{Social Capital}

Pierre Bourdieu (1985), who made a great contribution to the formation of the concept of social capital, defined it as "the sum of the existing or potential resources that develop on the basis of mutual relations and the 
networks they form" (p. 248). In other words, social capital is a whole which is formed by structures, such as norms, interpersonal connections, trust, etc. that strengthen cooperation and coordination for mutual benefits.

\section{Psychological Capital}

It was stated that psychological capital, which was put forward by being influenced by the positive trends in the wake of World War II, was a wealth beyond economic, human, and social capital. In this context, the psychological capital includes features that can be developed, such as self-efficacy, hope, optimism, resilience, etc. that individuals possess (Luthans \& Youssef, 2004, p. 148). A detailed explanation will be given in the following section.

Psychological capital focuses on understanding and improving the strengths and positive aspects of individuals and aims to teach individuals situations in which they can be happier, successful, and good. The concept of psychological capital has become the focal point of the business community in improving productivity and job performance. Positive psychological capital refers to the psychological development of an individual in a positive sense. With the development as mentioned above, individuals, by undertaking the tasks that seem difficult and in terms of displaying the necessary effort in order to accomplish these tasks successfully, must have features, such as being self-confident, thinking positively about achieving success in the present and future, showing effort to be successful within the scope of objectives and re-evaluating the paths to success that are needed when necessary, recovering, and continuing to achieve success even if it is covered with problems and troubles (Luthans, Youssef, \& Avolio, 2006, p. 3).

The dimensions of psychological capital directly affect professional and organizational identification, and they are also indirectly related to the levels of perception of professional life project. From this point of view, organizational and professional identification of employees is in close relationship not only with their individual skills but also with the use of these individual skills in their organizational and professional lives and turning them into success (Erkuş \& Findikl1, 2013, p. 310).

In working life, focusing only on the negative aspects of individuals' behaviors and considering the negative sides of all the consequences brought about the result that business life is evaluated as a ball of problems and employees are seen as people who disappear in this cycle and make things even more complex.

\section{Positive Psychology}

The three known goals of psychology in the historical process were to discover and educate gifted individuals by treating mental illnesses, providing a more livable life for individuals in good condition and finally revealing the potential of individuals (Hodges, 2010, p. 3).

The concept of positive psychology was first proposed by Abraham H. Maslow, Erich Fromm, and Carl Rogers in the context of humanistic psychology in 1960, which emphasizes the importance of psychology in terms of improving the existing problems of individuals as well as contributing to their happiness and personal development. In 1998, Martin E. P. Seligman, the president of the American Psychological Association, named the approach. Positive psychology is a new trend that focuses on the correctness rather than the mistakes that occur in individuals (Güler, 2008, p. 199).

As can be seen in Figure 1, it is interpreted that two different perspectives emerge according to organizations based on positive psychology and that the concept of positive psychological capital bears the characteristics of positive organizational behavior flow. 


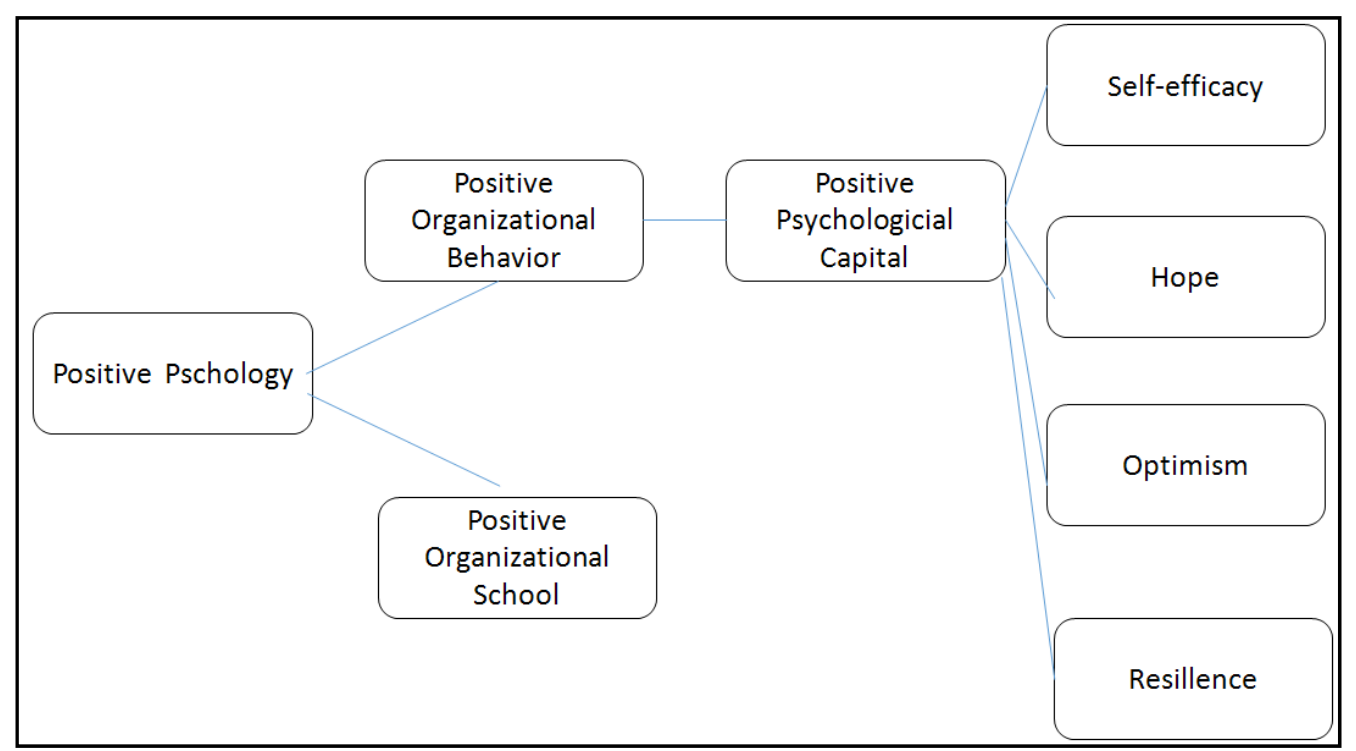

Figure 1. The relation of positive psychological capital with other concepts. Source: Luthans, Youssef, and Avolio (2006).

\section{A Research on the Measurement of Psychological Capital}

\section{Purpose and Scope of the Research}

The aim of this study was to measure the perception levels of the sub-dimensions of psychological capital, which are hope, resilience, optimism, and self-efficacy, in the employees of Mersin Municipality working in the status of civil servants and workers, and to determine whether there are significant differences in their psychological capital in terms of demographic variables, such as gender, age, marital status, working time, educational status, household income, and service period.

\section{Sample Selection and Data Collection}

In empirical research, it is very important that the sample number has a structure that provides robust results in order to avoid bias and systematic error in the process of data collection.

In this study, questionnaires were applied to the employees of Mersin Municipality civil servants and workers by face-to-face method. In the data entry phase, a total of 23 questionnaires were excluded from the analysis due to the fact that most of the questions were left blank, and a total of 431 questionnaires were used for the application. Six thousand and six hundred people work as civil servants and workers in Mersin Municipality. So, the total population is 6,600 people. When 10,000 people are considered as the total population in Table 1 , for $p=0.5$ and $q=0.5$, the sample of 370 is sufficient.

In this study, both group difference and relationship analysis will be performed. Power analysis was performed with $\mathrm{G}^{*}$ POWER 3.1 version in order to determine the potential of the number of the municipal employees who agreed to participate in the survey in terms of producing robust results. In the studies conducted by Cohen (1988) and Prajapati, Dunne, and Armstrong (2010), it was determined that statistical power at $1-\beta=$ 0.95 was sufficient, and the results were obtained by stating that relations and group differences would be calculated. Statistical significance level was determined as $\alpha=0.05$.

As a result of the power analysis, it was determined that the study would be valid if at least 115 samples were used. In this study, 431 samples were used and it was determined that the analyses to be performed would yield reliable results. 
Table 1

\section{Sample Size Table}

\begin{tabular}{|c|c|c|c|c|c|c|c|c|c|}
\hline \multirow{2}{*}{$\begin{array}{l}\text { Total population } \\
\text { size }\end{array}$} & \multicolumn{3}{|c|}{$\begin{array}{c} \pm 0.03 \text { sampling error } \\
\text { (d) }\end{array}$} & \multicolumn{3}{|c|}{$\begin{array}{l} \pm 0.05 \text { sampling error } \\
(\mathrm{d})\end{array}$} & \multicolumn{3}{|c|}{$\begin{array}{l} \pm 0.10 \text { sampling error } \\
\text { (d) }\end{array}$} \\
\hline & $\begin{array}{l}p=0.5 \\
q=0.5\end{array}$ & $\begin{aligned} p & =0.8 \\
q & =0.2\end{aligned}$ & $\begin{aligned} p & =0.3 \\
q & =0.7\end{aligned}$ & $\begin{array}{l}p=0.5 \\
q=0.5\end{array}$ & $\begin{aligned} p & =0.8 \\
q & =0.2\end{aligned}$ & $\begin{aligned} p & =0.3 \\
q & =0.7\end{aligned}$ & $\begin{array}{l}p=0.5 \\
q=0.5\end{array}$ & $\begin{array}{l}p=0.8 \\
q=0.2\end{array}$ & $\begin{array}{l}p=0.3 \\
q=0.7\end{array}$ \\
\hline 100 & 92 & 87 & 90 & 80 & 71 & 77 & 49 & 38 & 45 \\
\hline 500 & 341 & 289 & 321 & 217 & 165 & 196 & 81 & 55 & 70 \\
\hline 750 & 441 & 358 & 409 & 254 & 185 & 226 & 85 & 57 & 73 \\
\hline 1,000 & 516 & 406 & 473 & 278 & 198 & 244 & 88 & 58 & 75 \\
\hline 2,500 & 748 & 537 & 660 & 333 & 224 & 286 & 93 & 60 & 78 \\
\hline 5,000 & 880 & 601 & 760 & 357 & 234 & 303 & 94 & 61 & 79 \\
\hline 10,000 & 964 & 639 & 823 & 370 & 240 & 313 & 95 & 61 & 80 \\
\hline 25,000 & 1,023 & 665 & 865 & 378 & 244 & 319 & 96 & 61 & 80 \\
\hline 50,000 & 1,045 & 674 & 881 & 381 & 245 & 321 & 96 & 61 & 81 \\
\hline 100,000 & 1,056 & 678 & 888 & 383 & 245 & 322 & 96 & 61 & 81 \\
\hline $1,000,000$ & 1,066 & 682 & 896 & 384 & 246 & 323 & 96 & 61 & 81 \\
\hline 100 million & 1,067 & 683 & 896 & 384 & 245 & 323 & 96 & 61 & 81 \\
\hline
\end{tabular}

Source: Yazıcığlu and Erdoğan (2004, p. 50).

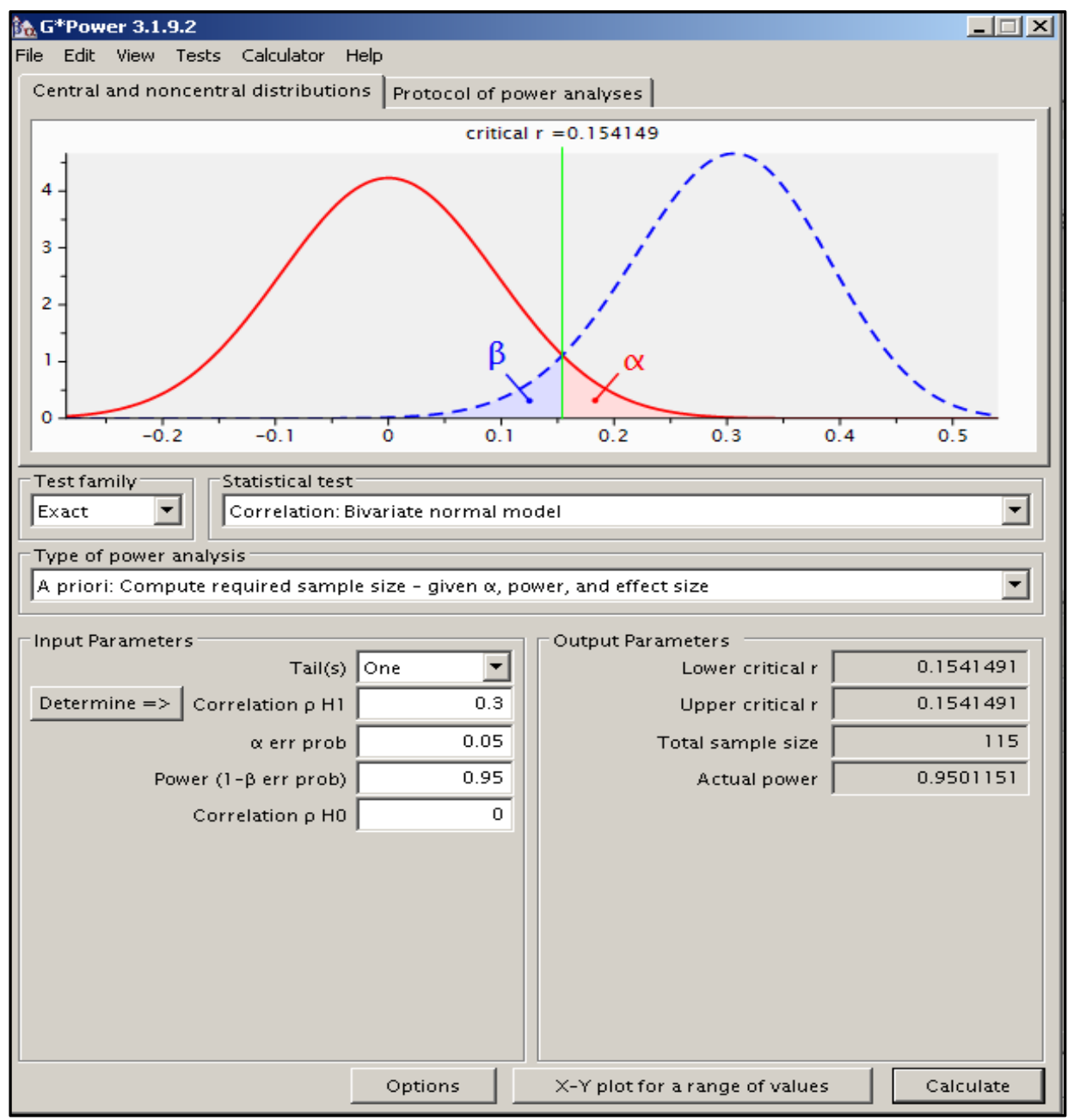

Figure 2. Power analysis results screen shot for correlation analysis. 


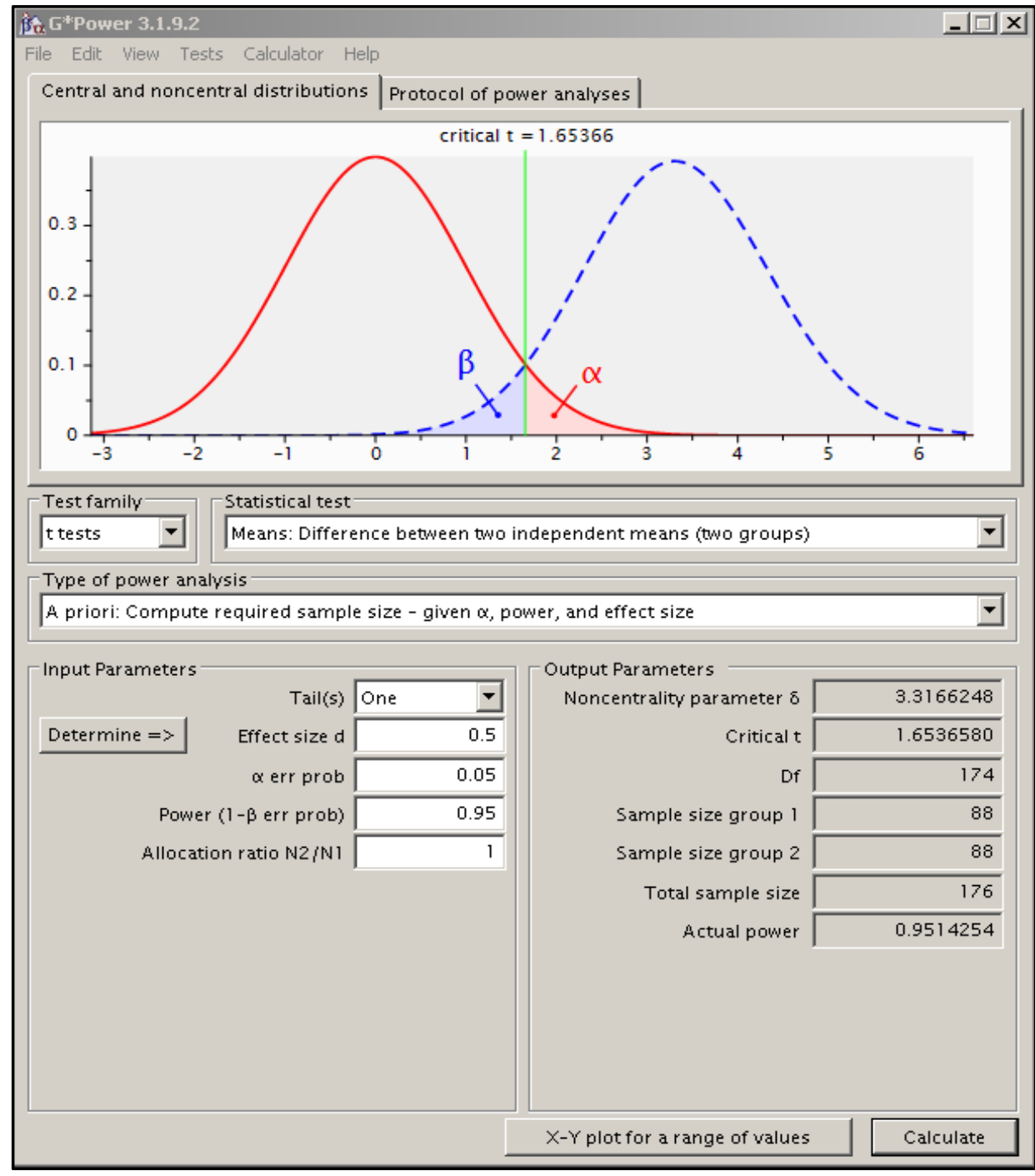

Figure 3. Power analysis results screen shot for group difference analysis.

As a result of the power analysis, it was determined that the study would be valid if at least 176 samples were used in group difference tests. In this study, 431 samples were used and it was shown that the analyses to be performed would be reliable.

\section{Assumptions and Limitations of the Research}

It was assumed that the participants expressed their true feelings and thoughts while answering the questions in the scale. It was accepted that the participants voluntarily responded to the questionnaire and answered it correctly and completely. It was accepted that the participants understood the words literally when answering the questions. Conceptual misconceptions that could occur were ignored.

There were some difficulties in increasing the number of samples in the survey and the employees stated that they would not participate in the study due to their intense work. The fact that employees did not view participation in the survey positively could be considered an important limitation. On the other hand, the survey was conducted during working hours between 02.12.2017 and 15.12.2017, and the employees who were on leave and were at hospital were excluded from the sample. 


\section{Data Collection Method and Tool}

In order to determine the level of psychological capital, a 24-item with 5-point Likert scale "PsyCap Questionnaire (PCQ)" developed by Luthans et al. (2007a; 2007b) was used. There are four sub-components of this scale. On the psychological capital scale, Items 1 to 6 measure optimism, 7 to 12 hope, 13 to 18 resilience, and 19 to 24 self-efficacy, respectively. Items 1,3 , and 16 on the scale are reverse questions and their codes are adapted when entering data to the computer. In the original scale, the number and order of the items are different. In this study, the format which was adapted to Turkish and tested for validity and reliability by Çetin and Basim (2012) was taken as the basis. The 5-point Likert scale used in the relevant sections of the questionnaire was coded as " $1=$ Never", " 2 = Rarely", " $3=$ Occasionally", " $4=$ Frequently", and " $5=$ Always". The first part of the questionnaire is intended to measure general and demographic information about the participants and the institution. The second part covers the psychological capital scale.

The Turkish adaptation of the psychological capital scale was made by Çetin and Basım (2012). And in that study which they carried out on two different samples, they found the reliability coefficients of the scale as 0.67 for optimism, 0.81 for hope, 0.68 for psychological resilience, and 0.85 for self-efficacy, and the overall reliability coefficient of the scale was found to be 0.91 , and thus they reported that the reliability and validity of the scale were acceptable.

\section{Hypotheses of the Research}

The hypotheses to be tested in line with the purpose of the research were determined as follows:

$\mathrm{H}_{1}$ : The "hope" dimension of psychological capital components varies across gender, age, marital status, working time, education level, household income, and service period.

$\mathrm{H}_{2}$ : "Resilience" dimension of psychological capital components varies across gender, age, marital status, working time, education level, household income, and service period.

$\mathrm{H}_{3}$ : The "optimism" dimension of psychological capital components varies across gender, age, marital status, working time, education level, household income, and service period.

$\mathrm{H}_{4}$ : The "hope" dimension of psychological capital components varies across gender, age, marital status, working time, education level, household income, and service period.

$\mathrm{H}_{5}$ : The components of psychological capital, hope, resilience, optimism, and self-efficacy are positively correlated with each other.

\section{Data Analysis and Findings}

\section{Research Method}

The data obtained from the scale used in the study were analyzed using IBM SPSS 22.0 package program. In the first stage, frequency distributions related to general information on demographic information were presented. In the second stage, reliability and validity analyses were performed by examining the distribution of the scale used in the study. Exploratory Factor Analysis (EFA) was used first to test the hypotheses. Afterwards, Kolmogorov-Simirnov and Shapiro-Wilk normality tests were performed for each dimension of the psychological capital scale, which was subdivided into sub-dimensions. Since the distribution of the data did not fit the normal distribution, in order to test group differences, Mann-Whitney-U test for each paired group and Kruskal Wallis tests for triple and multiple groups were performed. Mean rank values were examined to determine the source of the differences between the groups. Kendall's Tau-b correlation analysis was used to test the relationship analysis since the scale was not compatible with the normal distribution. 


\section{Questionnaire Reliability Analysis}

The most common tests to test the reliability of a scale are "Cronbach alpha, split-half, parallel, and absolute parallel (strict)". When Cronbach alpha test results are above $70 \%$, it indicates that the survey was successful. Some researchers expect this value to be over $75 \%$. The fact that the other reliability criteria are above $70 \%$ indicates that the internal consistency of the questionnaire is ensured and inferences can be trusted. As can be seen from Table 2, the percent values indicated and expected to be at the end of all four tests met the confidence criterion. Therefore, it was concluded that the sample results were consistent and reliable with high reliability values. Since all the reliability criteria that were considered exceeded $70 \%$, it was determined that the survey was successful, that the survey was consistent in itself, and that the results would reflect the real values.

Table 2

Reliability Analysis Results

\begin{tabular}{ll}
\hline & Reliability results of the questionnaire \\
\hline Cronbach alpha & 0.921 \\
Split & $0.920-0.923$ \\
Parallel & 0.920 \\
Strict & 0.922 \\
\hline
\end{tabular}

\section{Descriptive Analyses}

Frequency distribution analysis of demographic variables.

Table 3

Frequency Distribution Table for Gender Variable

\begin{tabular}{lllll}
\hline & Frequency & Percentage & Valid percentage & Cumulative percentage \\
\hline Male & 259 & 60.1 & 60.1 & 60.1 \\
Female & 172 & 39.9 & 39.9 & 100.0 \\
Total & 431 & 100.0 & 100.0 & \\
\hline
\end{tabular}

Table 4

Frequency Distribution Table for Educational Status Variable

\begin{tabular}{lllll}
\hline & Frequency & Percentage & Valid percentage & Cumulative percentage \\
\hline Primary school & 25 & 5.8 & 5.8 & 5.8 \\
High school & 122 & 28.3 & 28.3 & 34.1 \\
Associate degree & 130 & 30.2 & 30.2 & 64.3 \\
Bachelor's degree & 111 & 25.8 & 25.8 & 90.0 \\
Master's degree & 43 & 10.0 & 10.0 & 100.0 \\
Total & 431 & 100.0 & 100.0 & \\
\hline
\end{tabular}

Table 5

Frequency Distribution Table for Marital Status Variable

\begin{tabular}{lllll}
\hline & Frequency & Percentage & Valid percentage & Cumulative percentage \\
\hline Married & 205 & 47.6 & 47.6 & 47.6 \\
Single & 188 & 43.6 & 43.6 & 91.2 \\
Divorced/Widowed & 38 & 8.8 & 8.8 & 100.0 \\
Total & 431 & 100.0 & 100.0 & \\
\hline
\end{tabular}


Table 6

Frequency Distribution Table for Age Variable

\begin{tabular}{lllll}
\hline & Frequency & Percentage & Valid percentage & Cumulative percentage \\
\hline 29 and below & 144 & 33.4 & 33.4 & 33.4 \\
Between 30 and 39 & 193 & 44.8 & 44.8 & 78.2 \\
Between 40 and 49 & 77 & 17.9 & 17.9 & 96.1 \\
50 and above & 17 & 3.9 & 3.9 & 100.0 \\
Total & 431 & 100.0 & 100.0 & \\
\hline
\end{tabular}

Table 7

Frequency Distribution Table for Monthly Average Household Income Variable

\begin{tabular}{lllll}
\hline & Frequency & Percentage & Valid percentage & Cumulative percentage \\
\hline Less than 1,500 TL & 6 & 1.4 & 1.4 & 1.4 \\
$1,500-2,499$ TL & 21 & 4.9 & 4.9 & 6.3 \\
$2,500-3,499 \mathrm{TL}$ & 129 & 29.9 & 29.9 & 36.2 \\
$3,500-4,499 \mathrm{TL}$ & 170 & 39.4 & 39.4 & 75.6 \\
$4,500-5,500 \mathrm{TL}$ & 65 & 15.1 & 15.1 & 90.7 \\
More than 5,500 TL & 40 & 9.3 & 9.3 & 100.0 \\
Total & 431 & 100.0 & 100.0 & \\
\hline
\end{tabular}

Table 8

Frequency Distribution Table for Total Professional Service Period Variable

\begin{tabular}{lllll}
\hline & Frequency & Percentage & Valid percentage & Cumulative percentage \\
\hline 1 to 5 years & 133 & 30.9 & 30.9 & 30.9 \\
6 to 10 years & 122 & 28.3 & 28.3 & 59.2 \\
11 to 15 years & 87 & 20.2 & 20.2 & 79.4 \\
16 to 20 years & 63 & 14.6 & 14.6 & 94.0 \\
21 years and above & 26 & 6.0 & 6.0 & 100.0 \\
Total & 431 & 100.0 & 100.0 & \\
\hline
\end{tabular}

Table 9

Frequency Distribution Table for Working Period in the Current Institution Variable

\begin{tabular}{lllll}
\hline & Frequency & Percentage & Valid percentage & Cumulative percentage \\
\hline 1 to 5 years & 157 & 36.4 & 36.4 & 36.4 \\
6 to 10 years & 124 & 28.8 & 28.8 & 65.2 \\
11 to 15 years & 29 & 6.7 & 6.7 & 71.9 \\
16 to 20 years & 44 & 10.2 & 10.2 & 82.1 \\
21 years and above & 77 & 17.9 & 17.9 & 100.0 \\
Total & 431 & 100.0 & 100.0 & \\
\hline
\end{tabular}

Frequency distribution results for psychological capital scale dimensions. In the study, the average overall response rate was 4.13 for 4 dimensions. If the average response score of the participants was 4.13 and above, psychological capital perception was high and those who were below 4.13 had low psychological capital.

Table 10

Frequency Distribution Table for Mersin Municipality Employees' Perception of Psychological Capital

\begin{tabular}{lllll}
\hline & Frequency & Percentage & Valid percentage & Cumulative percentage \\
\hline Low perception of psychological capital & 147 & 34.1 & 34.1 & 34.1 \\
High perception of psychological capital & 284 & 65.9 & 65.9 & 100.0 \\
Total & 431 & 100.0 & 100.0 & \\
\hline
\end{tabular}


Table 11

Frequency Distribution Analysis for Optimism Dimension

\begin{tabular}{|c|c|c|c|c|c|c|c|c|}
\hline & Never & Rarely & Occasionally & Frequently & Always & \multicolumn{3}{|c|}{ Avg. \pm SD } \\
\hline $\begin{array}{l}\text { 1. In this workplace, things usually do not } \\
\text { run the way I want. }\end{array}$ & 1.9 & 2.1 & 11.1 & 6.5 & 78.4 & 4.58 & \pm & 0.904 \\
\hline $\begin{array}{l}\text { 2. When there are uncertainties for me in } \\
\text { my work, I always deserve the best. }\end{array}$ & 31.3 & 2.8 & 9.3 & 23.7 & 32.9 & 3.24 & \pm & 1.668 \\
\hline $\begin{array}{l}\text { *3. If something is going to go wrong for } \\
\text { me in my work, it definitely goes that way. }\end{array}$ & 14.4 & 14.4 & 17.4 & 11.4 & 42.5 & 3.53 & \pm & 1.501 \\
\hline 4. I always see the good side of my work. & 2.1 & 2.1 & 17.4 & 20.0 & 58.5 & 4.31 & \pm & 0.969 \\
\hline $\begin{array}{l}\text { 5. I am optimistic about what will happen } \\
\text { to me in the future regarding my work. } \\
6 \text {. I approach the events that I encounter }\end{array}$ & 2.1 & 4.4 & 12.3 & 18.8 & 62.4 & 4.35 & \pm & 0.995 \\
\hline $\begin{array}{l}\text { about my work saying "every cloud has a } \\
\text { silver lining". }\end{array}$ & - & - & 8.8 & 36.7 & 54.5 & 4.46 & \pm & 0.652 \\
\hline General & & & & & & 4.07 & \pm & 0.553 \\
\hline
\end{tabular}

Note. ${ }^{*}$ Percentage values are presented by adapting codes for inverse questions.

Table 12

Frequency Distribution Analysis for Optimism Dimension

\begin{tabular}{|c|c|c|c|c|c|c|c|c|}
\hline & Never & Rarely & Occasionally & Frequently & Always & \multicolumn{3}{|c|}{ Avg. \pm Sd } \\
\hline $\begin{array}{l}\text { 7. I am fulfilling the business goals I have } \\
\text { determined for myself at this time. }\end{array}$ & 3.9 & 4.9 & 12.5 & 11.4 & 67.3 & 4.33 & \pm & 1.114 \\
\hline $\begin{array}{l}\text { 8. I think there are many ways to solve any } \\
\text { problem. }\end{array}$ & 6.5 & 23.7 & 7.9 & 27.4 & 34.6 & 3.6 & \pm & 1.341 \\
\hline $\begin{array}{l}\text { 9. If I find myself in a dilemma while } \\
\text { working, I think of many ways to get rid of } \\
\text { this situation. }\end{array}$ & 1.9 & 7.9 & 15.1 & 49.0 & 26.2 & 3.99 & \pm & 2.149 \\
\hline $\begin{array}{l}\text { 10. I see myself as very successful in my } \\
\text { work right now. }\end{array}$ & 7.2 & 13.2 & 19.7 & 28.5 & 31.3 & 3.64 & \pm & 1.248 \\
\hline $\begin{array}{l}\text { 11. I strictly follow the objectives related to } \\
\text { my work. }\end{array}$ & & - & 10.2 & 33.9 & 55.9 & 4.46 & \pm & 0.673 \\
\hline $\begin{array}{l}\text { 12. I think of many ways to achieve my } \\
\text { current work goals. }\end{array}$ & 1.4 & 3.2 & 9.3 & 18.8 & 67.3 & 4.47 & \pm & 0.894 \\
\hline General & & & & & & 4.08 & \pm & 0.398 \\
\hline
\end{tabular}

Table 13

Frequency Distribution Analyses for Resilience Dimension

\begin{tabular}{|c|c|c|c|c|c|c|c|c|}
\hline & Never & Rarely & Occasionally & Frequently & Always & \multicolumn{3}{|c|}{ Avg. \pm Sd } \\
\hline $\begin{array}{l}\text { 13. If I have to, I can do my job on my } \\
\text { own. }\end{array}$ & - & - & 10.7 & 28.5 & 60.8 & 4.50 & \pm & 0.682 \\
\hline $\begin{array}{l}\text { 14. I feel that I can handle things that may } \\
\text { arise about my work on my own. }\end{array}$ & 1.4 & 33.4 & 20.6 & 21.8 & 22.7 & 3.31 & \pm & 1.193 \\
\hline $\begin{array}{l}15 . \text { I usually handle the difficulties in my } \\
\text { work in some way. }\end{array}$ & 5.3 & 22.0 & 19.5 & 37.6 & 15.5 & 3.36 & \pm & 1.142 \\
\hline $\begin{array}{l}{ }^{*} 16 \text {. When I encounter something wrong in } \\
\text { my work, I have trouble getting over it. }\end{array}$ & 17.9 & 17.9 & 16.9 & 16.0 & 31.3 & 3.25 & \pm & 1.500 \\
\hline $\begin{array}{l}\text { 17. I usually handle the stressful things in } \\
\text { my work in a calm way. }\end{array}$ & 2.3 & 9.3 & 23.0 & 26.0 & 39.4 & 3.91 & \pm & 1.095 \\
\hline $\begin{array}{l}\text { 18. Because I have had difficulties before, I } \\
\text { believe that I will overcome the difficulties } \\
\text { related to my work. }\end{array}$ & 0.9 & 1.4 & 5.6 & 66.1 & 26.0 & 4.15 & \pm & 0.659 \\
\hline General & & & & & & 3.74 & \pm & 0.518 \\
\hline
\end{tabular}

Note. ${ }^{*}$ Percentage values are presented by adapting codes for inverse questions. 
Table 14

Frequency Distribution Analysis for Self-Efficacy Dimension

\begin{tabular}{|c|c|c|c|c|c|c|c|c|}
\hline & Never & Rarely & Occasionally & Frequently & Always & \multicolumn{3}{|c|}{ Avg. \pm Sd } \\
\hline $\begin{array}{l}\text { 19. I trust myself when presenting } \\
\text { information to my colleagues. }\end{array}$ & 0.5 & 0.2 & 3.9 & 19.0 & 76.3 & 4.71 & \pm & 0.598 \\
\hline $\begin{array}{l}\text { 20. I trust myself in setting goals/objectives } \\
\text { in my work area. }\end{array}$ & 0.5 & 0.5 & 5.3 & 19.7 & 74.0 & 4.66 & \pm & 0.644 \\
\hline $\begin{array}{l}\text { 21. I trust myself in explaining my own } \\
\text { field of work in the meetings which also } \\
\text { include the management. }\end{array}$ & 0.7 & 2.1 & 5.6 & 19.0 & 72.6 & 4.61 & \pm & 0.748 \\
\hline $\begin{array}{l}\text { 22. I trust myself while trying to find a } \\
\text { solution to a long-term problem. }\end{array}$ & 0.2 & 2.3 & 10.4 & 17.9 & 69.1 & 4.53 & \pm & 0.791 \\
\hline $\begin{array}{l}\text { 23. I trust myself in contributing to the } \\
\text { discussions on the strategy of the } \\
\text { organization. }\end{array}$ & - & - & 9.7 & 27.8 & 62.4 & 4.53 & \pm & 0.667 \\
\hline $\begin{array}{l}\text { 24. I trust myself when contacting external } \\
\text { parties (suppliers, consumers) to discuss } \\
\text { problems. }\end{array}$ & - & - & 7.2 & 30.2 & 62.6 & 4.55 & \pm & 0.626 \\
\hline General & & & & & & 4.60 & \pm & 0.074 \\
\hline
\end{tabular}

\section{Exploratory Factor Analysis}

In the exploratory factor analysis process for the scales, the suitability of the data to factor analysis was first tested. Accordingly, the Kaiser-Meyer-Olkin (KMO) sample adequacy of the data set was found to be 0.935 , which is above the good value of 0.70 . The Bartlett sphericity test, which measures the consistency of the items/variables analyzed, was found statistically significant $\left(\chi^{2}=4581.367\right.$ and $\left.p=0.000\right)$. As a result of the tests, it was determined that the sample to be used for exploratory factor analysis was sufficient and the suitability of the factor analysis was determined.

After confirming the suitability of the data set with the tests, "varimax" rotation method and principal components analysis method were applied as factor retention method in order to reveal the factor structure. In the factor structure, a 4-factor structure explaining $76.79 \%$ of the total variance was determined. As a result of factor analysis, questions whose value is below 0.20 in the extraction column should be excluded from the analysis as Costello and Osborne (2005) stated that their effect on variance change is negligible.

In the studies conducted in the social sciences, the variance explained in the multi-factor designed between $40 \%$ and $60 \%$ is considered sufficient. Since the six dimensions explained $76.79 \%$ of the change in the variance, the explanatory rate of the factors was found to be sufficient.

\section{Group Difference Tests}

The normality test was applied to the factors obtained as a result of factor analysis.

Table 15

Normality Test

\begin{tabular}{lllllll}
\hline & \multicolumn{3}{c}{ Kolmogorov-Smirnov } & \multicolumn{3}{c}{ Shapiro-Wilk } \\
\cline { 2 - 7 } & Statistics & SD & $p$ & Statistics & SD & $p$ \\
\hline Optimism & 0.141 & 431 & 0.000 & 0.935 & 431 & 0.000 \\
Hope & 0.074 & 431 & 0.000 & 974 & 431 & 0.000 \\
Self-efficacy & 0.299 & 431 & 0.000 & 0.768 & 431 & 0.000 \\
Resilience & 0.055 & 431 & 0.003 & 0.978 & 431 & 0.000 \\
\hline
\end{tabular}


As can be seen in both normality test results, since $p<0.05$ value is obtained, $\mathrm{H}_{1}$ hypothesis is accepted, which indicates that normal distribution is not provided.

\section{Relationship Analysis}

It is accepted that there are significant relationships between optimism, hope, resilience, and self-efficacy, which are the dimensions of psychological capital, which is the sub-hypothesis of the study. Kendall's Tau-b correlation analysis was performed because the data did not provide a normal distribution.

Table 16

Relationship Analysis Results of Psychological Capital Dimensions

\begin{tabular}{lllllll}
\hline & & & Self-efficacy & Resilience & Optimism & Hope \\
\hline \multirow{4}{*}{ Self-efficacy } & $\mathrm{r}$ & 1 & $0.716^{*}$ & $0.734^{*}$ & $0.751^{*}$ \\
& & $\mathrm{p}$ & & 0.000 & 0.000 & 0.000 \\
& \multirow{2}{*}{ Resilience } & $\mathrm{r}$ & & 1 & $0.640^{*}$ & $0.699^{*}$ \\
& & $\mathrm{p}$ & & 0.000 & 0.000 \\
& Optimism & $\mathrm{r}$ & & & $0.796^{*}$ \\
& & $\mathrm{p}$ & & & 0.000 \\
& Hope & $\mathrm{r}$ & & & & 1 \\
\hline
\end{tabular}

Note. ${ }^{*}$ Statistically significant relationship for 0.05 and 0.01 .

As self-efficacy increases, resilience will increase to $71.6 \%$, optimism will increase to $73.4 \%$, and hope will increase to $75.1 \%$. As resilience increases, optimism will increase to $64 \%$, and hope dimension will increase to $69.9 \%$. As optimism increases, hope dimension will increase to $79.6 \%$. Positive and high relationships were determined between all dimensions. In order to increase the perception of psychological capital, it is necessary to increase the perception levels of the components. Thus, the sub-hypotheses were also confirmed.

\section{Conclusion and Suggestions}

Organizations aim to ensure the highest level of return in return for the products or services they produce. The traditional types of capital required for this purpose are not sufficient by themselves. Today, the fact that tools, such as economic capital, technology, R\&D studies, public relations, and marketing strategies can be replicated by competing organizations makes it difficult for organizations to gain edge in competition. At this point, the human factor comes into play.

Human capital is the most important type of capital for organizations. This precious capital affects business priorities and strategic perspective. Psychological capital is one of the factors that make significant differences in the performance of human capital. Today, many organizations expect their employees to be more creative, comment on the organization and take more responsibility. It has been determined that psychological capital is related to many positive results for employees and organizations in management research. Thus, the concept of psychological capital emerges as positive human resource capital, which continues to develop and continues to be studied with its potential elements.

The fact that employees with high psychological capital have better job performance makes it necessary for human resources managers to make more systematic and planned efforts to improve the psychological capital of employees in their organizations. First of all, exploratory studies can be carried out to determine the 
level of psychological capital of the current employees and their suitability with their jobs. For this purpose, the process of determining the "psychological capital profile" of the organization and the "organizational psychological capital profile" can be applied. These applications can be extended to include different business units. In the long term, it is possible to make more general inferences with averages on a sectoral and country basis.

In the study, all dimensions for gender differed statistically significantly. Women and men responded to psychological capital dimensions from different perspectives. Mean rank values were examined for the source of the difference. Women gave more positive answers to the optimism dimension (mean rank value was higher), men gave more positive answers to the hope dimension, men gave more positive answers to the resilience dimension, and women gave more positive answers to the self-efficacy dimension.

All dimensions for average monthly household income differed statistically significantly. While the psychological capital components were more positive as income increased, it decreased to negative as income decreased. In this case, income growth is a factor that strengthens psychological capital.

The psychological capital levels of the employees can be used as basic data in the stages of training planning, performance evaluation, and career planning. It can be ensured that psychological capital development trainings are taken in order to ensure the development of important business outputs, particularly performance improvement. In addition, while the data on psychological capital levels provide an important input in the performance evaluation process, in case of a decrease in performance, it can serve as an important tool for the identification and elimination of performance problems in individual, group, and departmental dimensions. These data can be used for career development goals in shifting employees to tasks that are appropriate to their level of psychological capital in the career planning, or training them for positions considered.

In addition, individuals' psychological capital data can be used as a "selection criterion" in the recruitment and placement process. By reviewing human resources policies and taking into account the nature of the work concerned, organizations can assign candidate employees to jobs that are appropriate to their psychological capital levels and use this information as a criterion for their placement in the appropriate job.

It may be possible to make the organization more authentic by making the organization more positive and more supportive in organizations in which employees with high psychological capital are employed due to the nature of the work. In addition, more opportunities will be provided for employees to turn their psychological capital into desired organizational outcomes. Although this process spans over a long period of time, the planned and systematic effort will enable the organization to gain competitive advantage and turn this power into a self-capability.

The most important quality of psychological capital is that its components of hope, optimism, self-efficacy and resilience are measurable and open to development. These features, which are stated to have an effect that increases performance, provides job satisfaction, and thus increases the happiness of the individual in working life, should be gained by individuals through the necessary trainings. In order to increase the level of positive psychological capital, to increase employees' commitment to the organization, and to ensure their continuity in the organization, employers need to create appropriate conditions for employees, support training and career plans, set achievable goals, reduce risks, and increase support and ensure that the employee is willing to stay in the organization through such practices. 


\section{References}

Abbas, M., \& Raja, U. (2011). Impact of psychological capital on innovative performance and job stress. The 14th International Business Research Conference, April 28-30, Dubai, United Arab Emirates.

Akçay, V. H. (2011). Pozitif psikolojik sermayenin kişisel değerler bakımından iş tatminine etkisi ve bir araştırma (Unpublished Ph.D. thesis, İstanbul Üniversitesi Sosyal Bilimler Enstitüsü, İstanbul).

Avey, J. B., Reichard, R. J., Luthans, F., \& Mhatre, K. H. (2011). Meta-analysis of the impact of positive psychological capital on employee attitudes, behaviours and performance. Human resource Development Quarterly, 22(2), 127-152.

Avey, J., Patera, J. L., \& West, B. J. (2006). The implications of positive psychological capital on employee absenteeism. Journal of Leadership and Organizational Studies, 13(2), 42-60.

Bakan, İ., Büyükmeşe, T., \& Bedestenci, H. Ç. (2004). Örgüt kültürü. İstanbul: Alfa Yayınları.

Bandura, A. (1982). Self-efficacy mechanism in human agency. American Psychologist, 37(2), 122-147.

Banerjee, P. M. (2013). Sustainable human capital: Product innovation and employee partnerships in technology firms. Cross Cultural Management, 20(2), 216-234.

Başar, E. E. (2012). Tüketici yenilikçiliği ve marka değeri algısının marka yayma üzerindeki etkileri (Master thesis, Atatürk Üniversitesi, Sosyal Bilimler Enstitüsü, Erzurum).

Begenirbaş, M., \& Turgut, E. (2014). Psikolojik sermayenin çalışanların duygu gösterimleri ve işe yönelik algılarına etkileri: Sağlık sektöründe bir araştırma. Örgütsel Davranış Kongresi Bildiriler Kitabı, 2, 181-193.

Borman, W. C., Hanson, M. A., \& Hedge, J. W. (1997). Personnel selection. Annual Review of Psychology, 48, $299-337$.

Bourdieu, P. (1985). The forms of capital. New York: Greenwood.

Cameron, K. S., Bright, D., \& Caza, A. (2004). Exploring the relationships between organizational virtuousness and performance. American Behavioral Scientist, 47, 766-790.

Çelik, M., \& Tabak, A. (2014). Çalışanların psikolojik sermaye seviyelerinin iş stresi ve işten ayrılma niyetleri üzerindeki etkisi: Turizm sektöründe bir araştırma. Örgütsel Davranış Kongresi Bildiriler Kitabı, 2, 157-167.

Çetin, F. (2011). The effects of the organizational psychological capital on the attitudes of commitment and satisfaction: A public sample in Turkey. European Journal of Social Sciences, 21(3), 373-380.

Çetin, F., \& Basım, H. N. (2012). Örgütsel psikolojik sermaye: Bir ölçek uyarlama çalışması. Amme İdaresi Dergisi, 45(1), 121-137.

Çetin, F., Şeşen, H., \& Basım, H. N. (2013). Örgütsel psikolojik sermayenin tükenmişlik sürecine etkileri: Kamu sektöründe bir araştırma. Anadolu Üniversitesi Sosyal Bilimler Dergisi, 13(3), 95-108.

Çınar, E. (2011). Pozitif psikolojik sermayenin örgütsel bağlllıkla ilişkisi. İzmir: Dokuz Eylül Üniversitesi Sosyal Bilimler Enstitüsü Yayımlanmamış Yüksek Lisans Tezi.

Cohen, J. (1988). Statistical power analysis for the behavioral sciences (2nd ed.). USA: Lawrence Erlbaum Associates Publication.

Coutu, D. L. (2002). How resilience works. Harvard Business Review, 80(5), 46-55.

Davis, K. (1984). İşletmede insan davranışı örgütsel davranış. (K. Tosun, Trans.). İstanbul: İ.Ü. Yayını.

Erkuş, A., \& Fındıklı, M. A. (2013). Psikolojik sermayenin iş tatmini, iş performansı ve işten ayrılma niyeti üzerindeki etkisine yönelik bir araştırma. İstanbul Üniversitesi, İşletme Fakültesi Dergisi, 42(2), 302-318.

Erkuş, A., \& Tüzün, A. (2014). İş yaşamında tinsellik, psikolojik sermaye, tükenmişlik ve iş performansı arasındaki ilişkilerin incelenmesi. Örgütsel Davranış Kongresi Bildiriler Kitabı, 2, 529-531.

Gohel, K. (2012). Psychological capital as a determinant of employee satisfaction. International Referred Research Journal, 3(36), 34-37.

Gooty, J., Gavin, M., Johnson, P. D., Frazier, M. L., \& Snow, D. B. (2009). In the eyes of the beholder: Transformational leadership, positive psychological capital, and performance. Journal of Leadership and Organizational Studies, 15(4), 353-367.

Görgens-Ekermans, G., \& Herbert, M. (2013). Psychological capital: Internal and external validity of the psychological capital questionnaire (PCQ-24) on a South African sample. SA Journal of Industrial Psychology, 39(2), 1-12

Güler, B. K. (2008). Pozitif psikoloji bakış açısından çalışma mutluluğu. In T. Solmuş (Ed.), İş ve Özel Yaşama Psikolojik Bakışlar (pp. 195-232). İstanbul: Epsilon Yayınları, 1. Baskı.

Harms, P. D., \& Luthans, F. (2012). Measuring implicit psychological constructs in organizational behavior: An example using psychological capital. Journal of Organizational Behavior, 33(4), 589-594. 
Hodges, T. D. (2010). An experimental study of the impact of psychological capital on performance, engagement and the contagion effect (Ph.D. dissertation, University of Nebreska).

Hodgson, G. M. (2014). What is capital? Economists and sociologists have changed its meaning: Should it be changed back? Cambridge Journal of Economics, 38, 1063-1086.

İpek, C. (1999). Resmi liseler ile özel liselerde örgütsel kültür ve öğretmen öğrenci ilişkisi (Unpublished Ph.D. thesis, Ankara Üniversitesi Sosyal Bilimler Enstitüsü, Ankara).

Judge, T. A., Jackson, C. L., Shaw, J. C., Scott, B. A., \& Rich, B. L. (2007). Self-efficacy and work-related performance: The integral role of individual differences. Journal of Applied Psychology, 92(1), 107-127.

Kaplan, R. E., \& Kaiser, R. B. (2010). Towards a positive psychology for leaders. In A. P. Linley, S. Harrington, and N. Garcia (Eds.), Oxford handbook of positive psychology and work (pp. 107-117). New York: Oxford University Press.

Karaaslan, M. H. (2012). Tüketici yenilikçiliği (Ph.D. thesis, Erciyes Üniversitesi, Sosyal Bilimler Enstitüsü, Kayseri).

Karataş, M., \& Çankaya, E. (2010). İktisadi kalkınma sürecinde beşeri sermayeye ilişkin bir inceleme. Mehmet Akif Ersoy Üniversitesi Sosyal Bilimler Enstitüsü, 2(3), 29-55.

Kaya, A., Yıldırım, M. C., \& Demirci, Z. (2014). Orta öğretimde görev yapan öğretmenlerin psikolojik sermaye düzeylerinin incelenmesi (şanlıurfa ili örneği). Elektronik Sosyal Bilimler Dergisi, 13(48), 47-68.

Keleş, H. N. (2011), Pozitif psikolojik sermaye: Tanımı, bileşenleri ve örgüt yönetimine etkileri. Organizasyon ve Yönetim Bilimleri Dergisi, 3(2), 343-350.

Koç, A. (2013). Beşeri sermaye ve ekonomik büyüme ilişkisi: Yatay kesit analizi ile ab ülkeleri üzerine bir değerlendirme. Maliye Dergisi, 165, 241-258.

Kozlu, C. (1986). Kurumsal kültür. İstanbul: Defne Yayıncılık.

Kümbül, G. B. (2012). Pozitif psikolojik sermaye: Tanımı, bileşenleri ve yönetimi. In A. Keser, G. Yılmaz, and Ş. Yürür (Eds.), Çalışma yaşamında davranış: Güncel yaklaşımlar (pp. 119-146). Kocaeli: Umuttepe Yayınları.

Larson, M. D., Norman, S. M., Hughes, L. W., \& Avey, J. B. (2013). Psychological capital: A new lens for understanding employee fit and attitudes. International Journal of Leadership Studies, 8(1), 28-43.

Larson, M., \& Luthans, F. (2006). Potential added values of psychological capital in predicting work attitudes. Journal of Organizational Studies, 13(1), 45-62.

Linley, P. A., Joseph, S., Harrington, S., \& Wood, M. A. (2006). Positive psychology: Past, present, and (possible) future. The Journal of Positive Psychology, 1(1), 3-16.

Luthans, F. (2010). Organizational behavior: An evidence-based approach (12th ed.). New York, NY: McGraw-Hill Companies Inc.

Luthans, F., \& Avolio, B. J. (2009). The "point” of positive organizational behavior. Journal of Organizational Behavior, 30(2), 291-307.

Luthans, F., \& Youssef, C. M. (2004). Human, social, and now positive psychological capital management: Investing in people for competitive advantage. Organizational Dynamics, 33(2), 143-160.

Luthans, F., Avey, J. B., \& Patera, J. L. (2008). Experimental analysis of a web-based intervention to develop positive psychological capital. Academy of Management Learning and Education, 7, 209-221.

Luthans, F., Avey, J. B., Avolio, B. J., \& Peterson, S. J. (2010). The development and resulting performance impact of positive psychological capital. Human Resource Development Quarterly, 21(1), 41-67.

Luthans, F., Avolio, B. J., Walumbwa, F. O., \& Li, W. (2005). The psychological capital of Chinese workers: Exploring the relationship with performance. Management and Organization Review, 1(2), 249-271.

Luthans, F., Youseff, C. M., \& Rawski, S. H. (2011). A tale of two paradigms: The impact of psychological capital and reinforcing feedback on problem solving and innovation. Journal of Organizational Behavior Management, 31(4), $333-350$.

Luthans, F., Youssef, C. M., \& Avolio, B. J. (2007). Psychological capital: Developing the human competitive edge (1st ed.). New York, NY: Oxford University Press Inc.

Luthans, F., Youssef, C. M., \& Avolio, B. J. (2006). Psychological capital: Developing the human competitive edge. USA: Oxford University Press.

Luthans, F., Yousseff, C. N., \& Avolio, B. J. (2007). Positive psychological capital: Investing and developing positive organizational behavior. In D. Nelson and C. L. Cooper (Eds.), Positive organizational behaviour: Accentuating the positive at work (p. 10). London: Sage Publications Ltd.

Luthans, F. (2002). Positive organizational behavior: Developing and managing psychological strengths. Academy of Management Executive, 16(1), 57-72. 
Norman, S. M. (2006). The role of trust: Implications for psychological capital and authentic leadership (Ph.D. thesis, University of Nebraska, Lincoln, United States of America).

Norman, S. M., Avey, J., Nimnicht, J. L., \& Pigeon, N. G. (2010). The interactive effects of psychological capital and organizational identity on employee organizational citizenship and deviance behaviors. Journal of Leadership and Organizational Studies, 17(4), 380-391.

Owens, R. G. (2004). Organizational behaviour in education: Adaptive leadership and school reform. Boston: Pearson Education.

Özgener, Ş., Demirtaş, Ö., \& Ulu, S. (2013). Kişi-Çevre uyumu ile sosyal tembellik ilişkisinde psikolojik sermayenin aracı rolü. Örgütsel Davranıs Kongresi, 1, 404-412.

Özkalp, E., \& Kırel, Ç. (2010). Örgütsel davranış. Bursa: Ekin Basım Yayın Dağıtım.

Özkalp, E., \& Meydan, B. (2014). Schaufeli ve bakker tarafından geliştirilmiş olan işe angaje olma ölçeğinin türkçe'de güvenilirlik ve geçerliliğinin analizi. Örgütsel Davranış Kongresi Bildiriler Kitabl, 2, 869-882.

Özkalp, E., \& Seçgin, S. (2013). Pozitif örgütsel davranışın örgütsel bağlllık üzerine etkilerini belirlemeye yönelik eskişehir'de yapılan bir araştırma. Ulusal Yönetim ve Organizasyon Kongresi, 21, 401-406.

Özkalp, E. (2009). Örgütsel davranışta yeni bir boyut: Pozitif (olumlu) örgütsel davranış yaklaşımı ve konuları. Ulusal Yönetim ve Organizasyon Kongresi Bildiriler Kitabl, 17, 491-498.

Peterson, S. J., \& Luthans, F. (2003). The positive impact and development of hopeful leaders. Leadership \& Organization Development Journal, 24(1), 26-31.

Prajapati B., Dunne M., \& Armstrong R. (2010). Sample size estimation and statistical power analysis. Optometry Today, 16(7), $1-9$.

Roberts, L. M., Spreitzer, G., Dutton, J., Quinn, R., Heaphy E., \& Barker, B. (2005). How to play to your strengths. Harvard Business Review, 83, 74-80.

Sabuncuoğlu, Z. (2004). İşletmelerde halkla ilişkiler. Bursa: Aktüel Yayınları.

Schulman, P. (1999). Applying learned optimism to increase sales productivity. Journal of Personal Selling \& Sales Management, 19(1), 31-37.

Seligman, M. E. P. (2006). Learned optimism: How to change your mind and your life (3rd ed.). New York, NY: Vintage Books.

Sivanathan, N., Arnold, K. A., Turner, N., \& Barling, B. (2004). Leading well: Transformational leadership and well-being. In P. A. Linley and S. Joseph (Eds.), Positive psychology in practice (pp. 241-255). New Jersey, NJ: John Wiley \& Sons Inc.

Stajkovic, A. D., \& Luthans, F. (1998). Self-efficacy and work-related performance: A meta-analysis. Psychological Bulletin, $124(2), 240-261$.

Şimşek, M. Ş. (2002). Yönetim ve organizasyon (7th ed.). Konya: Günay Ofset.

Şişman, M. (1994). Eğitimde mükemmellik arayışı. Ankara: Pegem A Yayınları.

Topaloğlu, T. (2013). Psikolojik sermaye geliştirilmesi üzerine bir uygulama ve performans üzerindeki etkileri. Örgütsel Davranıs Kongresi, 1, 476-480.

Topçu, M. K., \& Ocak, M. (2012). Psikolojik sermayenin tükenmişlik algısı üzerindeki etkisinde iş tatmininin aracılık rolü: türkiye ve bosna-hersek sağlık çalışanları örneği. Ulusal Yönetim ve Organizasyon Kongresi, 20, 24-26.

Tösten, R., \& Özgan, H. (2014). Pozitif psikolojik sermaye ölçeği: Geçerlik ve güvenirlik çalışması. EKEV Akademi Dergisi, $18(59), 429-442$.

Uslu, T. (2012). Mesleki Özdeşleşme açısından küçük işletmelerle büyük işletmelerin nitel ve nicel olarak kıyaslanması: Işyeri sahibi, yönetici ve çalışanlar arasındaki farklar. KOBI'ler ve Verimlilik Kongresi, 8, 34-42.

Walumbwa, F. O., Peterson, S. J., Avolio, B. J., \& Hartnell, C. A. (2010). An investigation of the relationships among leader and follower psychological capital, service climate, and job performance. Personnel Psychology, 63(4), 937-963.

West, B. J., Patera, J. L., \& Carsten, M. K. (2009). Team level positivity: Investigating positive psychological capacities and team level outcomes. Journal of Organizational Behavior, 30(2), 249-267.

Yazıcıŏlu, Y., \& Erdoğan, S. (2004). SPSS uygulamalı bilimsel araştırma yöntemleri. Ankara: Detay Yayıncılık 